\title{
The Development of Financial Economics in France between the Mid-1970s and the Early 1980s: Import or Rediscovery?
}

\author{
Franck Jovanovic, School of Business Administration - TELUQ University, Montreal, Canada, \\ CIRST (Canada), and LEO (France)
}

Guy Numa, Economics Department, Colorado State University, Fort Collins, USA*

Accepted for publication in History Of Political Economy (CNRS - 1; HCERES A)

\begin{abstract}
To date, little research has documented the international diffusion of financial economics. Financial economics was supposedly "introduced" in France in the 1970s. Some analysts have argued that it is an American author-Leonard J. Savage-who allowed French authors to rediscover Louis Bachelier's work, indicating that "a prophet is not without honor, save in his own country." The present article challenges this conventional narrative and studies for the first time how financial economics was disseminated in France between the mid-1970s and the early 1980s. It shows that, when financial economics was "imported" from the United States in France in 1970s, some pioneering French contributions have been taught for almost a century. Based on this result, the article explains why the French authors who disseminated these ideas rarely referred to the works of French forerunners. It also clarifies the role of the French economists in this process. All of this suggests that the "import" of financial economics in France was in fact a reintroduction.
\end{abstract}

Keywords: history of financial economics, Louis Bachelier, CESA-HEC JEL Classification: B26, B30, G10.

\footnotetext{
* Correspondence may be addressed to franck.jovanovic@teluq.ca. We are grateful to two anonymous referees and the editor of $H O P E$ for their helpful remarks. Translations are ours unless noted otherwise.
} 


\section{Introduction}

This article aims to study the reintroduction of financial economics in France between the mid1970s and the early 1980s. To date, except in rare cases (Jovanovic 2002c, Numa 2004), the diffusion of financial economics has been described as a process that originated in the US between the 1950s and the 1970s (Bernstein 1992, Davis and Etheridge 2006, Dimand 2009, Fourcade and Khurana 2013, Jovanovic 2008, Mehrling 2005, Poitras 2006, Poitras and Jovanovic 2007, Whitley 1986). ${ }^{1}$ The present essay challenges this conventional narrative and provides a different account of the diffusion of financial economics. By analyzing its diffusion in France in the 1970s and the 1980s, we show that some pioneering contributions made by French authors were already taught in some departments of economics and schools. However, the works of these precursors were overlooked by the French scholars who "imported" financial economics from the US. All of this suggests that financial economics was in fact reintroduced in France in the 1970s. It also suggests that the development of modern French finance neglected pioneering national contributions.

This article focuses on major theoretical works applied to financial markets: portfolio selection, Capital Asset Portfolio Management (CAPM), Efficient Market Hypothesis, and Black-ScholesMerton's option pricing model. Our research uses information collected from a survey sent to some of the key French actors of this reintroduction; we also conducted interviews with some of them. ${ }^{2}$ The data collected provide important insights into the training of French financiers and academics.

\section{Financial Economics in France before the 1970s}

While financial economics was reintroduced in France between the second half of the 1970s and the early 1980s, several of the key ideas in financial economics were formulated in France many decades before their formulation in the US. One can mention the random character of stock market prices, the proposition that the speculator's mathematical expectation of gain is zero, the benefits of diversification, the arbitrage opportunity in portfolio selection, and the diagram's representation in order to calculate the payoffs of complex combinations of financial assets.

This section revisits the ideas introduced by French authors before the 1970s. In addition, and central to our purpose, it shows that some of these ideas were taught and discussed in France at least until the 1950s. The analysis of this diffusion sheds some light on the fact that some pioneering ideas were overlooked by the French authors - particularly French economists - who reintroduced financial economics in France.

\subsection{The Creation of Financial Economics}

The foundations of modern stochastic models of asset price variations (i.e. the hypothesis of the random character of stock market prices, the Gaussian distribution of the stock market prices, and the proposition that the speculator's mathematical expectation of gain is zero) were stated for the first time in 1863 by a French broker's assistant, Jules Regnault. ${ }^{3}$ His book is the first work in

\footnotetext{
${ }^{1}$ In this essay, we focus on the development of ideas and models that apply to markets where decisions are made under uncertainty. This excludes corporate finance, which was still considered part of accounting in the mid-1970s.

${ }^{2}$ Seventeen individuals were contacted, and eleven of them responded. The information was collected based on four interviews and five surveys conducted in 2017 and 2018. The TELUQ University research ethics board provided an ethics certificate for this research. In accordance with the certificate, all the data collected are used anonymously, except for those who accepted to be quoted (i.e. Michel Albouy, Jean Dif, Jacques Hamon, Bertrand Jacquillat, Dominique Lacoue-Labarthe, Michel Levasseur, Yves Simon, and Richard Roll). We would like to thank all the interviewees for their participation and for their useful feedback on the latest version of the manuscript.

${ }^{3}$ For biographical details on Jules Regnault, see Jovanovic (2004, 2006b, 2018).
} 
financial economics known to this day (Edlinger and Parent 2014, Jovanovic 2009, Jovanovic and Le Gall 2001, Rutterford and Sotiropoulos 2015, Szpiro 2011). Moreover, in a very precursory way, Regnault validated his hypotheses with empirical data and (basic) statistical tests, like current financial economists do (statistical tests being one of the scientific criteria of financial economics). For instance, he used 900 monthly data from May 1825 to October 1862 of the 3\% rente-the main French public bond - for calculating periodical means and then testing, for each period, if the distribution of prices followed a normal law around these periodical means (Jovanovic and Le Gall 2001, Le Gall 2008). Regnault's ideas circulated widely in France and abroad. His ideas were used particularly among the most important French mathematicians interested in the application of mathematics to finance (Jovanovic 2018). At least two editions of Regnault's book were published with several reprints and favorable reviews, including one published by Alfred Darimon in the most important newspapers at that time. Darimon was a prominent financial columnist, economist, and secretary of Pierre-Joseph Proudhon. He was an active representative (député) in the National Assembly who specialized in economic and financial issues (Jovanovic 2018).

During the 1870s, a French actuary, Henri Lefèvre, published the first diagrams now commonly used for analyzing the payoffs of options or those of any complex combinations of financial assets, most notably combined primes, which were conditional forward contracts similar to options (Jovanovic 2002a, 2006a). ${ }^{4}$ Such diagrams were supposed to allow traders to perform tricky accounting calculations. Its ease of use considerably reduced response times to market fluctuations and sped up the flow of transactions, thus improving the circulation of goods and, beyond that, the functioning of the economy as a whole. Like Regnault, Lefèvre worked on financial markets, and like Regnault, Lefèvre's ideas also circulated widely in France (Jovanovic 2006a, Preda 2009). ${ }^{5}$ His graphical method was published in financial newspapers and circulated among brokers who worked at the Paris Stock Exchange. His work also inspired several French actuaries and some prominent late nineteenth-century French economists and statisticians interested in financial theory such as Léon Walras, Paul Leroy-Beaulieu, Arthur Raffalovich or Alfred Neymarck. In addition, Lefèvre was editor-in-chief of a financial newspaper, and professor at the Institut Polytechnique — not to be confused with the famous engineering school École Polytechniqueteaching a course in "higher financial education" and publishing numerous pedagogical works (Jovanovic 2006a, Taqqu 2001). These academic and professional positions contributed to spread his ideas.

Regnault's and Lefèvre's ideas were used and extended by another key author of the early history of financial economics, the French mathematician Louis Bachelier (Ben-El-Mechaiekh and Dimand 2018, Jovanovic 2000, 2012, Taqqu 2001). Bachelier's thesis is the first known work of mathematics applied to finance (Ben-El-Mechaiekh and Dimand 2018, Davis and Etheridge 2006, Dimand 1993, Jovanovic 2000, Taqqu 2001). This author was the first to apply the trajectories of Brownian motion and anticipated the mathematical finance developed since the 1960s (Taqqu 2001). As Ben-El-Mechaiekh and Dimand (2018) have shown, Bachelier published several articles and books, allowing him to improve his financial ideas until his last book on Speculation and calculus of probability published in 1938. Like Regnault and Lefèvre's works, Bachelier's ideas

\footnotetext{
${ }^{4}$ Profit charts analysis was also used in other European markets like in Berlin, for instance (Schmidt 2009, Weber 2009).

${ }^{5}$ At various times, he held positions as a banker, as the private secretary of Baron de Rothschild, and also worked for the Union, one of the largest insurance firms in Paris.
} 
were known by some of the most influential mathematicians of his time: his ideas directly contributed to the development of mathematical models and theories until the 1950s, particularly the modern theory of probabilities (Ben-El-Mechaiekh and Dimand 2018, Jovanovic 2012, Mehrling 2005). Some of the most important French (and international) economists and mathematicians interested in the application of mathematics to finance knew his work. Moreover, Bachelier taught in different universities (Courtault and Kabanov 2002). More specifically, from 1909 to 1914, he gave each year a series of twenty lectures on "Probability Calculus with Applications to Financial Operations and Analogies with Certain Questions from Physics" at the Faculté des Sciences of the Université de Paris (i.e. 1'Université de la Sorbonne, which was the most important university in France).

A few years after the publication of Bachelier's thesis, two famous French liberal economists who specialized in financial analysis, Leroy-Beaulieu (1906) and Neymarck (1913), discussed the benefits of diversification and arbitrage opportunity in the context of portfolio theory particularly (Edlinger and Parent 2014). Their ideas were influential and their works circulated widely among authors interested in economics and finance (Breton and Lutfalla 1991, Edlinger and Parent 2014). ${ }^{6}$ Both authors knew Lefèvre's and Regnault's works, proving that early financial economics ideas circulated among key French academic networks interested in finance.

To sum up, before World War I, several French authors had already published contributions that would later become the major foundations of financial economics between the 1950s and the 1970s. These ideas circulated and were common knowledge among some of the most important French (and also international) mathematicians and economists until the 1950s (Ben-ElMechaiekh and Dimand 2006, 2018, Jovanovic 2018, Taqqu 2001). Moreover, and it is crucial for our purpose, some pioneering works in financial economics were taught in France at least until the end of the 1950s in some of the major French universities, like the Université de Paris (Université de la Sorbonne) (Courtault and Kabanov 2002, Jovanovic 2002b, c, 2018). For instance, in the early 1900s, Herman Laurent and Alfred Barriol referred to Regnault's and Bachelier's works in their teaching on the application of mathematics to finance at the Université de Paris (Le Ferrand 2014, 5-6). We already mentioned that Bachelier gave lectures on finance at the Universite de Paris. In the same period, Julien Laferrière, a law professor at the Université de Lille, the Université de Strasbourg (1919-1929), and the Université de la Sorbonne (Faculty of law, 1929-1951), taught a course exclusively based on the work of Bachelier and Regnault (Jovanovic 2002b). In the same vein, Marcel Boll, a famous Physics professor who acknowledged Louis Bachelier for having proposed the theory of speculation and fair games (Boll 1936, 356) was a professor at the Université de Paris and also a professor at HEC Paris until he retired in 1956. ${ }^{7}$ As Schöttler (2015)

\footnotetext{
${ }^{6}$ Paul Leroy-Beaulieu (1843-1916) was a distinguished French economist. He managed the journal L'Économiste français from 1873 onwards. He was a member of the Société d'économie politique (and subsequently vice-president in 1893 and president in 1911). He also became a member of the Académie des Sciences Morales et Politiques and occupied the chair of political economy at the Collège de France in 1878. Alfred Neymarck (1848-1924) published many works in the field of political economy and particularly in finance. He founded the journal Le Rentier in 1869 and was a member (and subsequently president, in 1898) of the Société de Statistique de Paris.

${ }^{7}$ In HEC Paris, he was professor of Chemistry and Electricity.
} 
explains, Boll was a key popularizer of sciences in France and all of his publications were wellknown and circulated widely. ${ }^{8}$

\subsection{The Lack of Academic Community and Common Research Program}

Despite the diffusion of the works previously mentioned, these innovative ideas did not lead to the creation of a research program or a formal discipline in France (Jovanovic 2009). Moreover, as mentioned in section 3, the French academics who reintroduced these ideas in the 1970s and the 1980s by borrowing them from American economists apparently ignored the work of French precursors. How can we explain that these ideas were overlooked by French economists? This section unveils three major reasons: 1) the new ideas, 2) the French elitist system, and 3) the lack of organization of economics (and finance) in France and its subordination to law.

\subsubsection{Difficulty to accept pioneering ideas}

Having "pioneering" ideas often restricts their audience and their reception. It is well-known that most French economists during the $19^{\text {th }}$ century were against the use of mathematics and probability in economic science (Breton 1992, Ménard 1980). ${ }^{9}$ Such position limited the diffusion of Regnault's and Lefèvre's works among the French economists who were already established. Furthermore, financial economics was not easily accessible to non-specialists. One of the characteristics of financial economics is its close connection with modern probability theory, to which it owes its major results, hypotheses, and models. Indeed, the history of financial economics is closely linked with the history of modern probability theory (Davis and Etheridge 2006, Jovanovic 2008, Shafer and Vovk 2001). It is worth noting that it was only from the 1950s onwards that the tools of modern probability theory, particularly the Kolmogorov's axioms, became accessible to non-specialists, and hence to economists (Jovanovic 2008, Shafer and Vovk 2005, 54-5).

Before the 1950s, no common language existed and very few authors could read and understand, for instance, Bachelier's financial ideas even if these ideas were used by several mathematicians. Thus, Paul Lévy, a French mathematician who published major results on Brownian motion, believed that Bachelier 1913 article, which extended his thesis, contained an error (leading the French university where Bachelier applied for a permanent position to reject his application); in fact, Bachelier's work was devoid of any errors as Lévy conceded several years later (Ben-ElMechaiekh and Dimand 2006, Courtault and Kabanov 2002, Taqqu 2001). The situation changed after World War II. The American probability school, which emerged after the war, played a significant role in the creation and the diffusion of the standardized framework of modern probability theory. Thus, it is not by chance that American economists knew Bachelier's work in the 1950s thanks to Leonard J. Savage, an American mathematician. Savage translated the work on probability theory of French mathematician Émile Borel, who helped Bachelier obtain academic positions (Ben-El-Mechaiekh and Dimand 2006, Bernstein 1992).

\footnotetext{
${ }^{8}$ Boll's literary output was extremely prolific. Schöttler (2015) has tracked down seventy-one books or brochures or books edited, in addition to five hundred articles, columns, and reading notes published in the leading French scientific, philosophical and cultural journals and the general press.

${ }^{9}$ It should be noted, however, that the statement does not apply to all French liberals. Thus, engineer-economists such as Jules Dupuit and Clément Colson among others used mathematics in their writings. They were trained in engineering schools and were not subordinated to law faculties. For more details on the two traditions of French liberals trained in law and in engineering, see Le Gall (2007) and Numa (2017).
} 
To sum up, when modern probability ideas were in their infancy, French authors were active; but when modern probability theory became mainstream, their productivity and influence slowed significantly. Why did it happen outside France while the French school of mathematics contributed so much to the emergence of these new ideas for several decades? As Ben-ElMechaiekh and Dimand (2018) explained, the French lost their edge in all sciences given the fact that, unlike the UK, Germany or Russia who chose not to send their scientists to the battle front, graduates and students from the grandes écoles and universities were forced to complete their military service and many of them died during the first world war. ${ }^{10}$ Thus, it was mainly outside of France that research in probability theory was done and it eventually became mainstream. When the French pioneers in financial economics published their works, their contributions were not supported by an established framework, making the acceptance of these new ideas more difficult.

\subsubsection{The French Elitist System}

The French academic system is highly elitist with some distinctive characteristics that makes it unique. Ironically, this elitism is directly inherited from the French revolution, far from the ideal of "égalité" (equality), one of its keywords. An elitist academic system called grandes écoles was created to train technicians and army officers serving the French State. The creation of the elitist grandes écoles was a reaction against the universities. "Les grandes écoles, because they constitute the privileged access to the elites ... have impeded for a long time the emergence of universities which could be compared to those which shine abroad particularly in the area of the production of knowledge: as a result, because we did not succeed in making research a part of the activities of academics, a public institution entirely devoted to that purpose was eventually created [in November 1939,] the C.N.R.S." (Gouadain 1997, 8). ${ }^{11}$ The grandes écoles were not concerned with developing research and for a long time, economics and management did not have any place in the French academic system (see third reason below).

Moreover, this elitism, whose goal was to limit the possible development of universities, had (and still has) an extremely negative impact for developing new ideas that came from academics trained in universities. For example, Bachelier's major "mistake" was not to be too innovative for his time, but to have graduated from a French university while the French elite was essentially trained in the grandes écoles. As Paul Lévy, who graduated from a grande école, explained in his letter to Mandelbrot, he paid attention to Bachelier's work only when he realized that Kolmogorov cited him in 1931 (Courtault and Kabanov 2002, 66), and even in 1943 Levy had not really read Bachelier (Taqqu 2001). We previously mentioned the alleged "error" that Paul Lévy believed he had found in Bachelier's work based on only one page selected by Maurice Gevrey, one of Levy's colleague, who sought to prevent Bachelier from securing an academic position so he could recruit one of his friends. This was not the only incident. Paul Lévy was forced to acknowledge the claim of priority of another of Bachelier's publications during a lecture on "integrals whose elements are independent random variables" to the Société Mathématique de France on April 25,1934, 20 years after Bachelier's publication ("Comptes rendus des séances de l'année 1934", Bulletin de la Société Mathématique de France 62: 40-1). The situation was similar for Regnault, Lefèvre,

\footnotetext{
${ }^{10}$ For instance, 36\% of the students of the École Normale Supérieure (Mazliak 2015) and 29\% of the students of the École Polytechnique (Azzola 2014) died.

${ }^{11}$ For instance, in the Revue d'économie politique, which can be considered a journal reflecting the state of the academic production in the first decades of the $20^{\text {th }}$ century, one can notice that during the $1920 \mathrm{~s}$ and the $1930 \mathrm{~s}$ most of the articles dealt with economic issues and political economy debates. Theoretical articles were rare.
} 
LeRoy-Beaulieu, and Neymark. Because they did not graduate from the French grandes écoles, their ideas were generally ignored by the French elite. For instance, Lefèvre's ideas were used by the French actuary Léon Pochet (1873), a polytechnician (i.e. French engineer elite), without mentioning Lefèvre. In contrast, another French actuary, Hippolyte Charlon $(1878,1887)$ who did not graduate from the grandes écoles, cited Lefèvre when he used his ideas, although Charlon and Pochet knew each other.

Even if citing authors that come from one's own networks is a common practice everywhere, the opposition between the universities and the grandes écoles was (and is still) very strong in the French academic system (Bourdieu 1989). Both sides tend to ignore and delegitimize each other, as explained in the following section. This situation affected the transmission of early formulations of financial economics in France, because the elitist network of the grandes écoles rejected many contributions that did not come from its ranks. Consequently, it is not surprising that when financial economics emerged in France during the second half of the $19^{\text {th }}$ century and the early $20^{\text {th }}$ century (Jovanovic 2009), this field was ignored by the French elite, contributing to its marginalization.

\subsubsection{The Lack of Organization of Economics in France and its Subordination to Law}

The third reason which explains why, despite developing key ideas in financial economics, no research program or formal discipline emerged in France lies in the organization of the French academic system.

Nineteenth-century French economists were not prepared to acknowledge Jules Regnault's and Henri Lefèvre's contributions. There were no academic economics in France. Economics was introduced in Law faculties in 1877 (Breton and Lutfalla 1991, Le Van-Lemesle 1991), although the first chair in economics in a university setting was created in 1864 at the faculty of law of the Université de Paris and immediately filled by a lawyer. The legal scholars who controlled these faculties tightly controlled the faculty who could teach economics: only faculty who already had a position in the faculties of law could teach economics. Therefore, for a very long time the first professors in France who taught economics were lawyers (Marco 2006, 178). Consequently, some important and active nineteenth-century French economists such as Jean-Baptiste Say, Pellegrino Rossi, Paul Leroy-Beaulieu, Alfred Neymark, Charles Dunoyer, and Joseph Garnier, could not teach economics in the French faculties of law (https://www.contrepoints.org/2015/11/13/228864entretien-avec-serge-schweitzer-2). ${ }^{12}$ Unfortunately, as explained, it was among these French economists that financial economics emerged in France; but they could not teach them in the faculties of law.

The subordination of economics to law existed until 1968 in France (Marco 2006, 179), restricting the opportunities to teach financial economics. More precisely, until the end of the 1950s, economics and law were integrated in a single department (at least for undergraduate programs). Teaching was dominated by professors of law who were not open to economic ideas. Most of the young professors who taught economics were mainly trained in law, and teaching was mainly literary, avoiding statistics, mathematics and econometrics (Le Merrer 2011), which are crucial for financial economics. For instance, in his finance course taught until 1951, Laferrière presented

\footnotetext{
${ }^{12}$ However, it should be mentioned that among the French liberals, the most structured group of French economists,
} few were concerned with theoretical works. 
Regnault's and Bachelier's models in a strictly descriptive fashion without using any mathematics (Jovanovic 2002b). ${ }^{13}$ This situation was denounced by economists. For instance, in 1953 future Nobel Prize recipient Maurice Allais published an article in the Revue d'économie politique calling for the creation of faculties of economics separated from faculties of law.

It is only since the 1960s that economics became more autonomous and started to be organized at the academic level in France. In the 1950s and in the early 1960s some marginal reforms were passed to improve the teaching of economics - for instance, the bachelor's degree in economics was created in 1960, although this program, which was defined at the national level, still included numerous modules of law. Nonetheless, the significant changes occurred only in the mid-1960s. However, the organization of economics as an academic discipline in France did not happen overnight. For instance, despite the creation of three seminars dedicated to economics, such as the creation of the Séminaire de théorie économique Jean-Baptiste Say (associated with the Faculté de droit et des sciences économiques de Paris) in 1962, the participants in these new seminars were marginalized among academic economists. In the same vein, in 1967, Daniel Pilisi and Pascal Salin published a document about "Teaching and research in economics - the French situation" ("L'enseignement et la recherche en science économique - la situation française") that started with this sentence: "we consider that the current situation of teaching and research in economics in the French faculties of law and economics is extremely critical". They added that the scientific contribution of French scholars in theory and methodology was negligible. Some scholars "wanted to work like Anglo-Saxons. [They] were a minority that was marginalized compared to the main teachers in France" (Daniel Pilisi 1996 in Le Merrer 2011). ${ }^{14}$

Some key changes happened in 1968 with the social movement and protests in France called "mai 1968", largely supported by students. One of their requests concerned education in the universities. After the May 1968 events, a new law removed the faculties and reorganized the universities with new departmental structures ("Unités d'Enseignement et de Recherche") that led to the creation of economic departments. Economics became independent from law only in 1968. The creation of economic departments also considerably changed the economic curriculum: quantitative methods were introduced in teaching. It was a radical change that created several needs, particularly because there were almost no professors of economics in France who were able to teach such courses.

The lack of use of mathematics by French economists was not the only obstacle for the emergence of financial economics in French economic departments. The lack of interest in financial markets played an important role too. In the 1970s and until the mid-1980s, most French PhD students in economics had little exposure to financial markets and other financial economics topics except for those who became civil servants. For instance, Thierry Chauveau, a French financial economist who played an active role in the development of financial economics, ${ }^{15}$ defended his $\mathrm{PhD}$ dissertation in 1979 at the Université Paris-Dauphine on French bonds. While he gave a theoretical presentation of portfolio theory and CAPM, there was nothing about option pricing. Another

\footnotetext{
${ }^{13}$ The syllabus of the course reproduced in Jovanovic (2002b) shows that Laferrière mainly used Bachelier (1914), which introduced what would later be considered financial economics, but without mathematics.

${ }^{14}$ Note that economics was taught in some French grandes écoles (i.e. outside the French universities), and there was also a strong tradition of French engineer-economists (like Maurice Allais).

${ }^{15} \mathrm{He}$ was director of the famous master's degree in finance at Paris 1 Panthéon-Sorbonne (DEA monnaie-banquefinance) and also created the first laboratory in bank and finance in this university.
} 
example is Yves Simon. After a bachelor's degree in economics, he graduated from HEC Paris and defended his PhD dissertation at the Université Paris-Dauphine in 1971. Simon also played an important role in the introduction of financial economics in France. ${ }^{16} \mathrm{He}$ initially adopted a traditional approach in his work. Thus, his book about capital markets published in 1975 did not mention conditional contracts.

There were some rare exceptions among economists, though. For instance, Jean-Jacques Rosa (1972) who was trained in economics published the first paper in French about CAPM. Rosa published another article about CAPM in 1976 in the Revue économique that created a small debate (Mouillart 1977, Rosa 1976, 1977, Zajdenweber 1977). ${ }^{17}$ In 1974, he created with Dominique Lacoue-Labarthe and Georges Gallais-Hamonno, both trained in economics and key figures of the development of financial economics in France, the first master program in financial economics and the Institut orléanais de Finance at the Université d'Orléans. This institute became the Laboratoire d'économie d'Orléans (LEO) in 1996. ${ }^{18}$

The lack of interest in topics unrelated to government issues and the subordination of economics to law until 1968 explain why the French authors who reintroduced financial economics in the 1970s overlooked French precursors. In the 1960s and the 1970s, French economists focused on emancipating economics from lawyers. Moreover, as explained, the legal scholars who taught Bachelier's and Regnault's ideas in finance courses in universities could not master the mathematical tools necessary for research in financial economics. In other words, it seems that, with the emancipation and the institutionalization of economics, the financial knowledge was not transmitted to the next generation of economists because there was no natural conduit by which the knowledge could be easily transmitted.

\section{The Reintroduction of Financial Ideas in France}

While financial economics was almost nonexistent in French departments of economics, the situation was totally different in management science departments. More precisely, the institutionalization of management sciences in France between the end of the 1960s and the end of the 1970s created the opportunities for the reintroduction of financial ideas.

\subsection{The New Organization of Business Schools in France After World War II: an Opportunity for Introducing Financial Economics}

The institutionalization of management sciences in France took place in the context of a debate about the weakness of the French (and European) academic system compared to the dominant American system after World War II (Chessel and Pavis 2001, 14-6; 25-6). After this war, the US became the leader in economic and management research and teaching (Fourcade 2009). As early

\footnotetext{
${ }^{16}$ He created and headed the famous master's degree in finance at Université Paris-Dauphine (DESS 203 - Marchés financiers, matières premières et gestion des risques). He was also the academic editor of the finance and management series of Économica.

${ }^{17}$ As he explained to us, he was trained in Economics at the Université de Paris, Faculté de droit de Paris (Faculty of law). He defended his $\mathrm{PhD}$ dissertation in 1970 about economic development at the Université de Paris. He defended his thèse complémentaire on investments by insurance companies in which he used the works of Markowitz and Sharpe (1964). He learned financial economics through publications, and he did not go to North America.

18 Dominique Lacoue-Labarthe gave us the information about the master program.
} 
as the 1950s, in order to modernize management practices and teaching in Europe, the European Productivity Agency organized training courses and summer seminars in the US to train future European managers and teachers (Pavis 2003b, 75). French delegations were also sent to the US in order to study the organization of the American business schools. However, in the 1960s the weakness of the French university system was the subject of a public debate (Pavis 2003a). Two international reports - one from OECD (Platt 1963) and the other from UNESCO (Grégoire 1964) - pointed the weaknesses of the European system, in particular the French one. The gap between France and the US was particularly evident in management techniques and methods used in organizations and corporations.

This gap became a national concern in France. In Le défi américain (the American Challenge) published in 1967, Jean-Jacques Servan-Schreiber pointed out the gap between European countries and the US. The European countries appeared completely outclassed particularly in management techniques and methods. As Bertrand Jacquillat mentioned in his interview, the reorganization of teaching and research in French business schools took place in the context of the publication of this book. The introduction of modern methods of management, including finance, was one of the main concerns of Jean-Jacques Servan-Schreiber. In France, management sciences were not taught in universities but in business schools at that time. ${ }^{19}$ In order to reorganize themselves, French business schools changed their curriculum; they sought to give management its nobility by "scientizing" it, which means among other things to give a greater place to mathematics and to develop courses and programs in finance and management control. Up to that point, business schools mainly taught courses that did not form the core of management sciences, such as accounting and law, for instance. In this perspective, American business schools were viewed as models, and French academics took example from three of them: Harvard, Carnegie Institute of Technology (renamed Carnegie Mellon University in 1967), and Chicago (Pavis 2003a, 54).

HEC Paris is a good example of this reorganization and of the American influence. In the late of the 1950s, the Chambre de commerce et d'industrie de Paris pushed HEC Paris, which is part of its network, to become a sort of laboratory of the American business school model. As Jacquillat reminded, HEC Paris thus mimicked the major American universities and business schools. For instance, from 1965 HEC Paris introduced case studies in teaching by borrowing this approach from the Harvard business school which introduced it in the 1950s. The business school also changed its policy regarding its faculty. Like the American business schools, HEC Paris created permanent positions. While there was no permanent professor in 1962 in HEC Paris, there were 79 permanent professors in 1970. In addition, according to Jacquillat, in order to import American methods of management the French government allowed French students who just graduated from a MBA or a PhD program in the US to perform their mandatory military service as teachers at HEC Paris (rather than to perform a standard service in the military). It was the first time that schools such as HEC Paris opened permanent positions; before there were only lecturers, mainly professionals, except for economics and quantitative methods that were taught by professors who had a permanent position in universities. Thus, HEC Paris hired recent American PhD recipients on a temporary basis for creating new courses in finance. For instance, Jacquillat mentioned that

19 One exception was the IAE (instituts d'administration des entreprises). They were created in 1955 to teach management sciences in universities. Initially, they were complementary one-year programs (Chessel and Pavis 2001, $13)$. 
John G. McDonald was hired for two years in order to create the first courses in finance before he joined the Stanford Business School in 1968.

One of the key moments in the reorganization of management sciences in France was the creation of the Fondation Nationale pour l'Enseignement de la Gestion des Entreprises (FNEGE). ${ }^{20}$ This foundation was created in 1968 to boost the development of academic education in all the management fields (Chessel and Pavis 2001, Marco 2018, Pras 2018). One of its major roles was the creation of new staff of professors in management sciences mainly trained in the US (Pavis 2003a, 54). In the 1970s, and mostly between 1969 and 1973, the FNEGE gave scholarships to several students so they could pursue $\mathrm{PhD}, \mathrm{MBA}$ or master's degrees in the US. One of the fields targeted was financial economics. According to Jacquillat and Jean Dif, financial economics theories were reintroduced in 1972 when the FNEGE PhD students returned to France. These new $\mathrm{PhD}$ recipients took advantage of a radical change in the organization of business schools in France.

Initially, courses in financial economics were given only in the two major French business schools (HEC and ESSEC) then in universities. There was a fascination for the American research and teaching in finance as explained above. French students and professors also discovered financial economics thanks to visiting professors from the US, and in particular from the University of Chicago. For instance, John McDonald, Edward Altman and Richard Roll spent one or two years at HEC Paris, Richard Roll spent two years (1973-1975) in Brussels at the European Institute for Advanced Studies in Management (EIASM), ${ }^{21}$ and Eugene Fama one year (1975-1976) in at the EIASM, etc. From the beginning, the Universite Paris-Dauphine invited many American professors who gave seminars in its PhD programs. The FNEGE also funded visiting professor in the US. In order to receive the scholarship, the French professor had to work under the supervision of an American professor and to take some courses in the American Business school (Chessel and Pavis 2001, 109).

These scholarships had a crucial role in the reintroduction of financial ideas. First of all, nearly all of the key figures who reintroduced and developed financial economics in France have been funded by the FNEGE. These scholarships were crucial, because it is precisely in the American business schools that the institutional birth of financial economics took place in the US in the 1960s and 1970s (Fourcade and Khurana 2013, 2017). At that time, training in American business schools changed radically, becoming more "rigorous" and introducing quantitative approaches in their courses (Bernstein 1992, Chessel and Pavis 2001, 118, Fourcade and Khurana 2013, 2017, MacKenzie 2006, 72-3, Whitley 1986). They began to "academicize" themselves, recruiting increasing numbers of economics professors who taught in university economics departments such as Merton Miller (Fama 2008). Similarly, prior to offering their own doctoral programs, business schools recruited $\mathrm{PhD}$ students who were trained in university economics departments (Fourcade and Khurana 2013, Jovanovic 2008). The members of this new scientific community shared common tools, references, and problems thanks to new textbooks, seminars, and scientific

\footnotetext{
${ }^{20}$ National Foundation for Companies Management Academic Education.

${ }^{21}$ This institute was established in 1971 with the support of the Ford foundation. "EIASM's mission is to enhance high quality in research and doctoral studies in management and related disciplines" (https://www.eiasm.net/about_eiasm/mission-statement). One of the requirements was to invite American scholars from the University of Chicago (Chessel and Pavis 2001, 72-4).
} 
journals. The two main journals specialized in finance, the Journal of Finance and the Journal of Business, changed their editorial policy during the 1960s. Both started publishing articles based on modern probability theory and on modelling (Bernstein 1992, 41-44, 129). Consequently, French $\mathrm{PhD}$ and MBA students enjoyed a very stimulating environment in the US and in Canada, as unanimously confirmed by all of the interviewees who studied in North America on a FNEGE scholarship. Some of them, like Jacquillat, have explained to us that they felt they participated in the emergence of financial economics. In addition, several of them mentioned that they chose studying finance because it was the most rigorous sub-field in management sciences at that time.

A second key moment was the creation of the Centre universitaire Dauphine in 1968, which became the Université Paris-Dauphine in 1970. This institution is considered in France a grande école and not a university per se (and it is not by chance that this "university" obtained the status of "grand établissement" in 2004 and is no longer legally an university). ${ }^{22}$ This university, focused on management and applied economics, was created in order to provide some answers to the education and teaching issues that were denounced by students during the May 1968 protests (Chessel and Pavis 2001, Pavis 2003a, 99-101). Here again, the goal was to improve the French university education system by adopting the American model, and more specifically by imitating the Harvard Business School. The Universite Paris-Dauphine became the leading French university in financial economics; it also created one of the first computer databases on Paris stock market prices, the AFFI-SBF database. This database was created at the request of the French Association of Finance (AFFI) and the Société des bourses françaises. The creation of such computer databases was crucial for developing research programs in France (see section 3.3). Interestingly, as mentioned by Jacquillat, one of its faculty, the mathematician and Fields medal recipient Pierre Louis Lyons, helped French and American economists and managers write articles in finance. Given the role of mathematics in financial economics, having a professor of this caliber in its faculty was important.

Finally, it is worth mentioning the last aspect of the institutionalization of management sciences in France: the creation of $\mathrm{PhD}$ and professors in management sciences since the mid-1970s. With the foundation of the Centre universitaire Dauphine, the head of this center and the FNEGE spearheaded the project of the aggrégation of management sciences-an examination that intended to constitute the gateway to full professorship - given the increasing number of students in this field in France, particularly in the 1970s (Marco 2006). However, it was only in 1976 that this examination was created (Chessel and Pavis 2001, Marco 2006). FNEGE also contributed to the creation of a PhD in management sciences. In other terms, it was only in the mid-1970s that French academics could open themselves to a new approach such as financial economics. The first programs dedicated to financial economics were created only in 1987 (master's programs).

\subsection{What do French Textbooks "Teach" us?}

Textbooks play a key role in defining and stabilizing a scientific culture, which will be shared by the members of a community; they also provide an indication about the evolution of a discipline (Augello and Guidi 2012, Giraud 2018, Kuhn 1962, Medema 2011, Montagne 2017, Teixeira 2018, Vicedo 2012). This section aims to assess the role of textbooks in the reintroduction of what

\footnotetext{
${ }^{22}$ One of the main reasons behind the change of legal status was to legalize the right for Dauphine to select its students, as by law French universities have open admission policies. Until 2004, this practice was implemented in violation of French laws that applied to universities.
} 
became financial economics in France. To do so, we analyze their structure and contents. It is assumed that there is a strong connection between the publication of textbooks and the teaching of financial economics. The texts analyzed here were not published to educate the masses or enlighten public opinion; instead, they were used to train future managers and economists at the advanced undergraduate and graduate levels.

Until the mid-1970, there was no textbook on financial economics in the French language. Consequently, as Jacquillat explained, in their teaching the new French professors translated American articles or provided summaries of American articles. The major references for studying finance were Rosenfeld (1963), ${ }^{23}$ Depallens (1970), ${ }^{24}$ and Conso (1975). ${ }^{25}$ The three textbooks share a similar approach of teaching finance until the mid-1970s in France. They are mainly descriptive and literary; they mainly focus on accounting and financial management; financial markets and direct finance are missing. These three authors were teachers and practitioners. Their texts present a practical approach of finance as opposed to a more theoretical one later adopted from the mid-1970s. ${ }^{26}$

Rosenfeld (1963) textbook was used by students of the Institut de Statistique de l'Université de Paris (ISUP), where Félix Rosenfeld was a professor. In 1961, Rosenfeld offered to teach a course in financial analysis to the director of ISUP. He used his experience as a financial analyst and portfolio manager in the investment bank Banque de Paris et des Pays-Bas (that became Paribas in 1982) since 1955 (Rosenfeld 2002, Théodore 2008). The textbook is very descriptive (only ten pages out of one hundred and fifty contain analytical developments). Rosenfeld points out in his textbook the need for using mathematics and modeling (the professor Jacques Lesourne makes similar statements in the forewords of the book); indeed, students enrolled at the ISUP were well-trained in statistics and mathematics and thus were perfectly able to handle technical courses. However, the content of the book is literary, except for basic mathematics for calculating the discounted value; it does not explain how statistics could be used for finance or for corporate decision making. It also contains several pages for learning chartism. Furthermore, the notion of risk is always discussed from a qualitative standpoint, no objective methods of calculation are given.

Depallens (1970) textbook was used by several generations of students since the 1960s. It was considered as the "Bible" for learning finance (Albouy 1995) and was called "le Depallens". This textbook is based on a vision of finance devoid of financial markets. The study of financial statements (particularly the balance sheet) forms a large part of the textbook. All of the issues related to direct finance (portfolio management, etc.) are missing; banking appears to be the only source of financing considered by the author.

\footnotetext{
${ }^{23}$ Félix Rosenfeld (1915-2007) graduated from ISUP, the only institution training statisticians in France until the foundation of ENSAE in 1942. Having collaborated with Georges Darmois and Emile Borel at the Henri Poincaré Institute Laboratoire de Statistique, he soon became a member of the Société de Statistique de Paris. He wrote his thesis on actuarial science from the Institut des Finances et des Assurances in 1939. He was president of the Société statistique de Paris, among other things. He also taught statistics to financial analysts in the Training Center for financial analysis and portfolio management in Geneva and was director of the center. He was a founding member of the training center of the SFAF (French Society of Financial Analysts) in 1963.

${ }^{24}$ A graduate of HEC Lausanne, Georges Depallens was a former Chief Financial Officer of SNECMA, known today as Safran Aircraft Engines. He was a former professor at IAE of the Université de Paris.

${ }^{25}$ Pierre Conso is a businessman and an academic. He was a professor at HEC Paris, at the Universite Paris-Dauphine, at the Centre national des Arts et Métiers (CNAM), and at Paris-Sorbonne University.

${ }^{26}$ The situation was exactly the same for French textbooks dedicated to corporate finance: until the mid-1970, they were mainly descriptive and they ignored financial economics (Charreaux 2006, 7; fn 17).
} 
The last textbook, Conso (1975), also presents a practical approach of finance. It is a voluminous title published in two volumes of about three hundred and fifty pages each. Unlike the previous two references, there is a modest effort to discuss some theoretical advances. Like Depallens (1970), the study of financial statements is a major theme (about a third of volume one). Except for a brief mention of Modigliani and Miller in volume two, the book does not discuss topics in financial economics. It should be noted that the author inserted a short appendix on basic mathematics for finance such as formulas for calculating simple and compounded interest rates and calculating present value.

The first textbooks devoted to financial economics in France are Rosenfeld (1972), Jacquillat and Solnik (1974), Vernimmen (1976) and Zisswiller (1976). In his 1972 textbook, Félix Rosenfeld abandoned the descriptive approach used in his first textbook. Among these four textbooks, Jacquillat and Solnik deserves a special attention, because, according to all of our interviewees, it was considered the reference by students and professors during the $1970 \mathrm{~s}$ and the $1980 \mathrm{~s} .{ }^{27}$ This textbook appeared in ten printings and editions from 1974 to 2014. The first edition was published after Jacquillat was visiting professor at Stanford Graduate School of Business in the summer of 1974. It was also after that summer that Solnik, who was assistant professor at Stanford University Graduate school of business, returned to France. The first edition included discussions of CAPM, Markowitz's model, and Efficient Market Hypothesis - which the authors called "the theory of random character of stock market" - but nothing about the work of Black and Scholes on option pricing theory, which would be included in the second edition published in $1976 .{ }^{28}$ Starting with the third edition of 1981, the Efficient Market Hypothesis was presented as the "théorie du marché efficient", the literal French translation.

Markowitz's model (1952) appears for the first time in Rosenfeld (1972). ${ }^{29}$ This textbook presents the model over three pages (out of three hundred and eighty-five). Rosenfeld (1972) does not provide enough explanation to be able to understand all of the ideas of portfolio management. His mentioning of Markowitz's work is brief. For instance, neither graphical analysis nor detailed calculations support the presentation. In contrast, Jacquillat and Solnik (1974) and Zisswiller (1976) contain graphs and calculations. Jacquillat and Solnik (1974) are more complete and discuss Markowitz's model over six pages out of two hundred and fifty. Like Rosenfeld (1972), Jacquillat and Solnik (1974) mention that the calculations required a powerful computer, which suggests that they were not able to run empirical tests.

\footnotetext{
${ }^{27}$ Bertrand Jacquillat was born in 1944 in Paris. He is a graduate of HEC, Institut d'Études Politiques de Paris and Harvard. He also holds a doctorate in management and the agrégation of management. He was a professor at HEC, Stanford, and Berkeley. He was a former Vice-President of the Université Paris-Dauphine (1989-91). Since 1994, he is the co-founder and CEO of Associés en Finance, a consulting firm in the financial industry. Associés en Finance advised the French stock market regulator during the period of systemic reforms of the Paris stock exchange in the 1980s (implementation of electronic trading system, creation of the French financial derivatives exchanges MONEP and MATIF, etc.).

Bruno Solnik graduated from École Polytechnique and holds a $\mathrm{PhD}$ in finance from MIT. He became assistant professor at the Stanford University Graduate business school before moving to HEC Paris and École Polytechnique in 1974. He also taught during these first years a course in the master program in financial economics in Orléans.

${ }^{28}$ In the second edition, Jacquillat and Solnik discuss Black and Scholes on option pricing, but they overlook the contribution of Robert C. Merton (1973).

${ }^{29}$ Rosenfeld (1970) mentions Markowitz's 1959 book in a footnote.
} 
CAPM is another idea examined in the textbooks. For instance, Vernimmen (1976) based his presentation on the first version of Sharpe's market model. ${ }^{30} \mathrm{He}$ uses the term "market model" instead of "CAPM". Yet, all the equations and explanations show that it is indeed CAPM. The book appeared in 1976 at a time where the term "CAPM" was generic and already used by other French authors such as Jacquillat and Solnik (1974). For his part, Zisswiller (1976) presents CAPM as a standard utility maximization problem by a rational investor. He uses the model to analyze three investment projects (Zisswiller 1976, 110-4). It is the only textbook that questions the validity of CAPM and criticizes its assumptions (Zisswiller 1976, 101-3).

As for the work of Black and Scholes on option pricing theory, the most convincing presentation is that of Jacquillat and Solnik (1976). In the first edition of their textbook, Jacquillat and Solnik did not discuss option pricing theory. Option pricing models were introduced in finance courses in France around 1976. Michel Levasseur mentions that he included Black and Scholes in his senior year teaching only from 1977. After that, he noted that continuous-time financial analysis became mainstream in advanced courses in the early 1980s. Jacquillat and Solnik presentation is simple and accessible for undergraduate students. Besides the empirical tests performed by Black et Scholes themselves in the US, Jacquillat and Solnik mention some tests performed on the French market. Unlike other models discussed in their book, Jacquillat and Solnik fail to explain why option pricing theory à la Black and Scholes could be useful for professionals. However, it should be mentioned that Yves Simon started teaching Futures in his courses about international finance in 1969 when he was teacher assistant at HEC (he did not publish a textbook at this time). Yves Simon discovered futures and future market in 1969 when he went to Winnipeg for a three-month training period as a student in HEC. ${ }^{31}$

It is important to note that French textbooks discussed option pricing while at that time in France (and in several other European countries) standardized option contracts did not exist; until 1965 only premium contract (called "prime") — a conditional forward contract similar to an option, but with some differences (Courtadon 1982, Cuoco and Barone 1989) -were traded at the Paris Stock Exchange. This kind of contract was introduced in France in 1718 by John Law in order to impress people and stimulate purchases of shares of the Banque Générale (Jovanovic 2017). Prime contracts were taken off the Paris Stock Exchange after the collapse of Law system and reintroduced in 1844 (Weber 2009, 455); in contrast, options were traded at the London Stock Exchange. ${ }^{32}$ Prime market was considerable on the Paris Stock Exchange during the $19^{\text {th }}$ and the $20^{\text {th }}$ centuries. For instance, in 1980 there were 13.319 millions of prime contracts traded for a total of 105 millions of francs compared to 2 millions of option contracts for a total of 66 millions of francs (Solnik and Stevenin 1981, 562). In 1965, when option contracts were introduced at the Paris Stock Exchange, they were not standardized contracts, they were over-the-counter options. Prime contracts disappeared in France in 1987 with the creation of the MONEP, which was the French corporation responsible for the management and the surveillance of the French equity derivatives market. MONEP introduced standardized option contracts. In other words, primes and over-the-counter options were both traded at the Paris Stock Exchange between 1965 and 1987.

\footnotetext{
${ }^{30}$ In fact, the market model was the first version of Sharpe's algorithm contained in his $1961 \mathrm{PhD}$ thesis, which aimed to simplify Markowitz's portfolio selection.

${ }^{31}$ Yves Simon had a complete training about futures: he visited a farm in order to discover how futures were used by farmers for their risk management, then by a broker company, and finally by the Winnipeg future market.

32 On the history of option contracts, see Poitras $(2000,2009)$.
} 
From a methodological standpoint, we can observe the influence of the new financial ideas that emerged in the US on some positions defended by the French authors. For instance, Jacquillat and Solnik $(1974,3-4 ; 12-16)$ criticize the chartist analysis in the same way the first American financial economists did to justify the new discipline in the 1960s (Jovanovic 2008, Whitley 1986). Jacquillat and Solnik describe the geometric forms identified by chartists as esoteric; similarly, the first American financial economists claimed that chartism was based on folklore.

Two conclusions can be drawn from our analysis of textbooks. First, no text published in the 1970s and the early 1980s referred to the French pioneers in financial economics such as Bachelier or Regnault; yet, there are reasons to believe that some authors heard of them or knew their work. Consider, for instance, the case of Bachelier. Jacquillat and Solnik (1974, 1976, 1981) presented the "theory of random character of stock market" and option pricing model and discussed most of the articles published in Cootner (1964) in which Bachelier's thesis was translated for the first time in English; but they totally overlooked Bachelier. ${ }^{33}$ Solnik (1973) mentioned Moore (1964) in his discussion of the origins of the random walk model, but he did not mention Bachelier (1900 [1964]) yet Moore's contribution is published in Cootner (1964). However, Jacquillat and Solnik apparently knew Bachelier's work at some point in the mid- to late 1970s. Thus, Jacquillat mentioned Bachelier in a 1979 working paper, but surprisingly not in the third edition of his textbook coauthored with Solnik that was released in 1981. For his part, Solnik was an assistant professor of finance at the Stanford University Graduate School of Business up to 1974, while Jacquillat was a visiting professor in the same school. In 1974, Cootner was a professor at Stanford and he supervised the Finance workshop. Similarly, Daniel Zajdenweber - who was a member of the CESA like Jacquillat and Solnik and all of the key authors who reintroduced financial economics in France - cited Bachelier in his 1975 CESA working paper. The document was presented at the Congress on "Recherches récentes en finance et l'économie monétaire" organized by the FNEGE and the business school ESSEC that same year. In this working paper, he thanked Jacquillat and Levasseur for their help (note 1, page 3). Zajdenweber also mentioned Bachelier in his $\mathrm{PhD}$ thesis defended in 1972 at Université Paris 1 Panthéon-Sorbonne. Bachelier is briefly mentioned in Levasseur and Simon $(1980,29)$, but not in the bibliography. According to Michel Levasseur, Bachelier's work circulated in French academia in the late 1970s. Michel Levasseur acknowledged that he printed out a few dozen copies of Bachelier's thesis that he distributed. However, most of the French authors did not refer to Bachelier, except some rare authors such as Daniel Zajdenweber who worked with Benoit Mandelbrot (a French scholar who revisited Bachelier's pioneering contributions).

Second, our analysis sheds greater light on the dissociation between economics and management, which took place in French academia circa 1975-1976 (Savall 1985). One can conclude that these textbooks contributed to make financial economics a part of management rather than a part of economics, and thereby contributed to the autonomization and the institutionalization of management in France. This is especially true considering the fact that most of the authors of these textbooks, though trained in universities for some, were affiliated with business schools where the teaching of management and finance was emerging. ${ }^{34}$ In a sense,

\footnotetext{
${ }^{33}$ Cootner is a prominent financial economist and a key figure of the emergence of financial economics (Jovanovic 2008). He started his career at MIT and later joined the faculty of the Graduate School of Business at Stanford University in 1970.

${ }^{34}$ One exception has been the Université Paris-Dauphine which, as previously mentioned, greatly contributed to the development of management and financial economics.
} 
financial economics gained its autonomy from economics (as explained in the following section), but it developed in business schools where traditional "old school" finance (accounting) was taught for a long time.

\subsection{Organization of research in financial economics}

One major aspect of the reorganization of French business schools was the introduction of research in these institutions. As some of our interviewees noted, at that time some academics realized that they lagged behind the US in terms of research output and quality. Their response was simply to "import" what was done in the American business schools and to mimic how American business schools worked. Indeed, in the 1970s and the 1980s, most of the research in financial economics came from students trained in management.

In order to measure the importance of this influence on research, it is worth reminding that HEC Paris was created in 1881, more than 25 years before the Harvard Graduate School of Business Administration (1908). Moreover, HEC Paris was not the first business schools in France. French higher business education started with the creation of École Spéciale de Commerce by JeanBaptiste Say and trader Vital Roux in Paris in 1819. The establishment was the world's first business school now known as ESCP Europe (Blanchard 2009, Kaplan 2014). ${ }^{35}$ Although older than the Harvard Business School, until the 1980s HEC Paris and ESCP had no influence on research, in contrast to the Harvard Graduate School of Business Administration. Research was completely ignored by HEC Paris until it adopted the model of the American business schools. In this context, the newly developed research programs in the American business schools, particularly in financial economics and new microeconomics, were "imported" in a completely empty research environment.

The FNEGE also played a key role in the creation and the development of a scientific community devoted to financial economics. When the first scholars who received a FNEGE-sponsored scholarship returned from the US, one strategy of the FNEGE was to help them land a professorial posts in a small number of business schools or universities (Chessel and Pavis 2001, 121). This foundation partly funded the first seminars dedicate to financial economics' ideas, and in particular the Louis Bachelier seminar created in $1968 .^{36}$ These seminars took place at ESSEC, HEC and in the headquarters of the FNEGE. Moreover, the FNEGE created in 1975 a scientific journal dedicated to management sciences, Revue française de gestion, which published some articles in financial economics (Barraux 2016). In addition to seminars, some workshops and annual conferences were organized from the mid-1970s with the financial support of the FNEGE. The CESA at HEC published the working papers of the professors, in particular in finance, and organized a workshop on Finance in 1974 and Sharpe was one of the participants. ESSEC organized the Journées internationales de finance in 1978 and 1979. ${ }^{37}$ Then, from 1979, another

\footnotetext{
${ }^{35}$ The goal was to offer practical training in line with the needs of entrepreneurs and independent from universities. Initially an independent institution, the school suffered financial difficulties and was bought by the Paris Chamber of Commerce in 1869.

${ }^{36}$ Jean Dif explained to us that this research seminar was launched by Alain Galesne (professor at the Université de Rennes). The meeting took place in the headquarters of the FNEGE, and participants were mainly trained in mathematics or engineering.

${ }^{37}$ The CESA was a kind of holding of HEC group that included the school of HEC per se, the Institut Superieur des Affaires (ISA), the Continuing Education Center and later the Research Directorate. At the end of the 1990s, the name HEC was retained to name the entire group.
} 
key association also organized seminars in financial economics, the Association française de finance (AFFI). This professional association also played an important role in the institutionalization of research in financial economics in France. It was created on January $18^{\text {th }}$, 1979 by nine academics: Florian Aftalion, Marc Bertoneche, Alain Chevalier, Michel Levasseur, Joël Malkin, Jean Merigot, Maurice Nussenbaum, Roland Perez, and Richard Zisswiller. The AFFI aimed to play a similar role as the American Finance Association (AFA). A scientific journal, Finance, was created in $1980 .{ }^{38}$ Finance was the main academic journal that published articles in financial economics in France. From 1979, the AFFI also organized an annual congress dedicated to financial economics.

Another key figure of the introduction of research in financial economics in France was the CESA at HEC Paris. Bertrand Jacquillat participated in the creation and the development of the CESA as Director and Professor of International Teacher's Program in 1973. He played a key role in the introduction of financial economics (see section 3.1.). He convinced Bruno Solnik, a new assistant professor of finance at the Stanford Graduate School of Business, to join the faculty of HEC Paris in 1974. Trained in France, Solnik defended his PhD thesis in finance at the MIT Sloan School of Management in 1972 before moving to Stanford. There was a strong connection between the Stanford Graduate School of Business and the CESA. Jacquillat was a visiting professor at Stanford Graduate School of Business during the summers of 1974, 1975, 1979, 1980, and 1984; he was also a visiting professor from 1976 to 1978 as he replaced Sharpe during his sabbatical leave. Several professors from Stanford were also visiting professors at the CESA, such as John G. McDonald. The CESA provided the computer support to construct a database of French stock market prices and to test models (Altman, Jacquillat, and Levasseur 1974). Unlike the US, there were almost no computers in France at this period. As Jean Dif has explained, the FNEGE scholars were dazzled by the extent of resources they discovered in North America (easy access to the computers, access to databases, time sharing, etc.). ${ }^{39}$

Finally, the influence of the University of Chicago's ideas in finance, which looks very strong among French authors trained in the US. First, several visiting professors from American universities came from Chicago. For instance, Fama and Roll were visiting professsors at the European Institute for Advanced Studies in Management in Brussels, Belgium; in 1981, Fisher Black was an invited speaker at the AFFI annual conference. This gave French academics the opportunity to invite American professors in their universities. For instance, Jean Dif recalled that Fama visited the Faculté des Sciences économiques of the Université de Rennes. He was invitated by Alain Galesne who, like Dif, attended the Université de Sherbrooke in Canada through a FNEGE scholarship in 1970-71. As Yves Simon clarified, Richard Roll had a significative

\footnotetext{
${ }^{38}$ There were other journals that published articles about finance (for instance, Banque, Banques et Marché, la Synthèse financière, and Analyse financière), but they targeted professionals.

${ }^{39}$ Jean Dif started his career in 1953 as a professional worker at the Compagnie des Machines Bull, a French company created in 1930, which was one of the first companies that created the first punched cards and the first computers. He joined the Caisse des dépôts et consignations (CDC) in 1956 and became computer scientist in 1961. In 1970, while working at the CDC, he received a one-year scholarship from the FNEGE to study at the Universite de Sherbrooke (Québec, Canada). He graduated with a master's degree in finance in 1973. He received his doctorate degree in 1974 at the Université de Rennes (France) on convertible bonds, which are similar to option contracts (http://jean.dif.free.fr/CUVI.html). At the CDC, he was working in a research group with other academics, such as Thierry Chauveau. As a computer engineer, he developed programs and mathematical models in particular for pricing convertible bonds. In addition to working at the CDC, he taught finance as a lecturer in several French universities.
} 
influence on the first French authors. It was during his visit at the CESA that Roll wrote his article that criticizes the CAPM.

\section{Conclusion}

The reintroduction of what became financial economics in France has several paradoxes and issues that can be investigated with additional research. However, two crucial elements can be pointed out: the lack of reference to French precursors and the lack of consideration for French specificities.

Our investigation has unveiled that, while ideas of French pioneers were taught in France until the 1950s, French academics failed to capitalize on their national scientific knowledge when they reintroduced financial economic ideas in the 1970s and the 1980s. We have showed that key French actors who disseminated financial economics at that time were affiliated with business schools and departments of management not with departments of economics. Moreover, what we can call the "American training label" (being trained in the US with a FNEGE scholarship) was an important and very efficient career boost (Pavis 2003b). This could explain why no textbook published in the 1970s and the early 1980s referred to the French pioneers in financial economics such as Bachelier, though it seems obvious that some authors had heard of them or knew their work.

This lack of reference to French precursors in finance underlines the strong influence of ideas from the US at that time, and the conflictual relationships between French academics. American authors and institutions were viewed as modern, while French authors represented the past. Management scholars used this symbolism to distinguish themselves from economists who were not really rewarded for their work in financial economics because they were mainly concerned with dissociating themselves from lawyers. In this perspective, while Jacquillat knew Bachelier in 1979 he did not consider his work important enough to investigate ideas from French precursors; American scholars apparently came first in his mind. As Jean Dif explained, "North American financial science was more advanced and better formalized than in France", and French authors "seemed far behind us considering what we learned in North America." Moreover, it seems that French academics "imported" financial models, theories and concepts without considering French specificities. As shown in our discussion of option pricing in textbooks, they adopted them rather than adapting them.

\section{References}

Albouy, Michel. 1995. "Les transformations de l'enseignement de la gestion financière." In Mélanges en l'honneur du professeur André Page: formation et sciences de gestion, edited by Michel Albouy, 15-27. Grenoble: Presses Universitaires de Grenoble.

Altman, Edward I., Bertrand Jacquillat, and Michel Levasseur. 1974. "Comparative Analysis of Risk Measures: France and the United States." The Journal of Finance 29 (5):1495-1511.

Augello, Massimo M., and Marco E. L. Guidi, eds. 2012. The Economic Reader: Textbooks, Manuals and the Dissemination of the economic sciences during the nineteenth and the early twentieth centuries. London and New York: Routledge.

Azzola, Olivier. 2014. Les polytechniciens de la Grande Guerre (1914-1918) morts pour la France : repères et chiffres. École polytechnique - France: Centre de Ressources HistoriquesBibliothèque de l'X.

Bachelier, Louis. 1900 [1964]. "Theory of speculation." In The random Character of Stock Market Prices, edited by Paul H. Cootner, 18-91. Massachusetts: MIT. 
Bachelier, Louis. 1914. Le jeu, la chance et le hasard, Bibliothèque de philosophie scientifique. Paris: E. Flammarion.

Barraux, Jacques. 2016. "Comment est née la « Revue française de gestion »." Revue française de gestion 254 (1):11-15.

Ben-El-Mechaiekh, Hichem, and Robert W. Dimand. 2006. "Louis Bachelier." In Pioneers of Financial Economics, Volume 1: Contributions Prior to Irving Fisher, edited by Geoffrey Poitras, 225-237. Cheltenham: Edward Elgar Publishing.

Ben-El-Mechaiekh, Hichem, and Robert W. Dimand. 2018. "Louis Bachelier's 1938 Monograph on the Calculus of Speculation: Mathematical Finance and Randomness of Asset Prices in Bachelier's later work." Revue d'histoire des mathématiques 24 (1):41-106.

Bernstein, Peter L. 1992. Capital ideas : the improbable origins of modern Wall Street. New York and Toronto: Free Press; Maxwell Macmillan Canada; Maxwell Macmillan International.

Blanchard, Marianne. 2009. "From 'Ecoles Supérieures de Commerce' to 'Management Schools': transformations and continuity in French business schools." European Journal of Education 44 (4):586-604.

Boll, Marcel. 1936. La Chance et les Jeux de Hasard. Paris Larousse.

Bourdieu, Pierre. 1989. La noblesse d'Etat. Paris: Les éditions de minuit.

Breton, Yves. 1992. "L'économie politique et les mathématiques en France, 1800-1940." Histoire et Mesure 7:25-52.

Breton, Yves, and Michel Lutfalla. 1991. L'Economie politique en France au XIXe siècle. Paris: Economica.

Charlon, Hippolyte. 1878. Théorie mathématique des opérations financières. Paris: GauthierVillars.

Charlon, Hippolyte. 1887. Théorie élémentaire des opérations financières (2ème édition). Paris: Gauthier-Villars.

Charreaux, Gérard. 2006. "Théorie financière et stratégie financière." Revue française de gestion 160 (1):109-137.

Chessel, Marie-Emmanuelle, and Fabienne Pavis. 2001. Le technocrate, le patron et le professeur: une histoire de l'enseignement supérieur de gestion. Paris: Belin.

Conso, Pierre. 1975. Gestion financière de l'entreprise, 4ème éd. Paris: Dunod.

Cootner, Paul H. 1964. The random character of stock market prices. Cambridge, Mass.: M.I.T. Press.

Courtadon, Georges. 1982. "A note on the premium market of the paris stock exchange." Journal of Banking and Finance 6 (4):561-565.

Courtault, Jean-Michel, and Youri Kabanov. 2002. Louis Bachelier: aux origines de la finance mathématique. Besançon: Presses Universitaires Franc-Comtoises.

Cuoco, Domenico, and Eugenio Barone. 1989. "The Italian market for 'premium' contracts: An application of option pricing theory." Journal of Banking \& Finance 13 (4):709-745.

Davis, Mark, and Alison Etheridge. 2006. Louis Bachelier's Theory of speculation. Princeton and Oxford: Princeton university press.

Depallens, Georges. 1970. Gestion financière de l'entreprise, 4ème éd. Paris: Sirey.

Dimand, Robert W. 1993. "The case of Brownian motion: a note on Bachelier's contribution." British Journal for the History of Science 26 (2):233-234.

Dimand, Robert W. 2009. "The Cowles Commission and Foundation on the functioning of financial markets from Irving Fisher and Alfred Cowles to Harry Markowitz and James Tobin." Revue d'Histoire des Sciences Humaines 20:109-130. 
Edlinger, Cécile, and Antoine Parent. 2014. "The beginnings of a 'common-sense' approach to portfolio theory by nineteenth-century French financial analysts Paul Leroy-Beaulieu and Alfred Neymarck." Journal of the History of Economic Thought 36 (1):23-44.

Fama, Eugene F. 2008. "Interview with Professor Eugene Fama by Professor Richard Roll." August 15.

Fourcade, Marion. 2009. Economists and societies: discipline and profession in the United States, Britain and France, 1890s to 1990s. Princeton: Princeton University Press.

Fourcade, Marion, and Rakesh Khurana. 2013. "From Social Control to Financial Economics: The Linked Ecologies of Economics and Business in Twentieth-Century America." Theory and Society 42 (2):121-159.

Fourcade, Marion, and Rakesh Khurana. 2017. "The Social Trajectory of a Finance Professor and the Common Sense of Capital." History of Political Economy 49 (2):347-384.

Giraud, Yann. 2018. Textbooks in the history of recent economics: the case of Samuelson's Economics. In A Contemporary Historiography of Economics, edited by E. Roy Weintraub and Till Düppe. Oxon: Routledge.

Gouadain, Daniel. 1997. "Les universites et l'enseignement de la gestion : histoire d'une rencontre tardive." IAE de Poitiers.

Grégoire, Roger, ed. 1964. Les sciences sociales dans l'enseignement supérieur: administration des entreprises. Edited by L'Enseignement des sciences sociales. Paris: UNESCO.

Jacquillat, Bertrand. 1979. "Les processus de diffusion et leur utilisation dans l'évaluation des actifs financiers conditionnels." CESA, Working paper.

Jacquillat, Bertrand, and Bruno Solnik. 1974. Les marchés financiers et la gestion de portefeuille. Paris: Dunod.

Jacquillat, Bertrand, and Bruno Solnik. 1976. Les marchés financiers et la gestion de portefeuille, 2ème éd. Paris: Dunod.

Jacquillat, Bertrand, and Bruno Solnik. 1981. Les marchés financiers et la gestion de portefeuille, 3ème éd. Paris: Dunod.

Jovanovic, Franck. 2000. "L'origine de la théorie financière: une réévaluation de l'apport de Louis Bachelier." Revue d'Economie Politique 110 (3):395-418.

Jovanovic, Franck. 2002a. "Instruments et théorie économiques dans la construction de la "science de la Bourse" d'Henri Lefèvre." Revue d'Histoire des Sciences Humaines 7:41-68.

Jovanovic, Franck. 2002b. "La Loi Juridique et la Loi Scientifique de la Bourse par Julien Laferrière." Revue d'Histoire des Sciences Humaines 7:181-191.

Jovanovic, Franck. 2002c. "Le modèle de marche aléatoire dans la théorie financière quantitative."Ph. D. thesis, University of Paris 1, Panthéon-Sorbonne.

Jovanovic, Franck. 2004. "Eléments biographiques inédits sur Jules Regnault (1834-1894), inventeur du modèle de marche aléatoire pour représenter les variations boursières." Revue d'Histoire des Sciences Humaines 11:215-230.

Jovanovic, Franck. 2006a. "Economic instruments and theory in the construction of Henri Lefèvre's "science of the stock market"." In Pioneers of Financial Economics, vol. 1, edited by Geoffrey Poitras, 169-190. Cheltenham: Edward Elgar.

Jovanovic, Franck. 2006b. "A nineteenth-century random walk : Jules Regnault and the origins of scientific financial economics." In Pioneers of Financial Economics, vol. 1, edited by Geoffrey Poitras, 191-222. Cheltenham: Edward Elgar.

Jovanovic, Franck. 2008. "The Construction of the Canonical History of Financial economics." History of Political Economy 40 (2):213-242. 
Jovanovic, Franck. 2009. "Le modèle de marche aléatoire dans l'économie financière de 1863 à 1976." Revue d'Histoire des Sciences Humaines 20:81-108.

Jovanovic, Franck. 2012. "Bachelier: not the forgotten forerunner he has been depicted as." European Journal for the History of Economic Thought 19 (3):431-451.

Jovanovic, Franck. 2017. "An introduction to the Calculation of the Chance: Jules Regnault, his book and its influence." Working paper.

Jovanovic, Franck. 2018. "New elements on Jules Regnault's Calcul des chances et philosophie de la bourse [Calculation of the Chance and Philosophy of the Stock Market]: a very well diffused book and new connections with Louis Bachelier ", Working paper.

Jovanovic, Franck, and Philippe Le Gall. 2001. "Does God practice a random walk? The "financial physics" of a 19th century forerunner, Jules Regnault." European Journal for the History of Economic Thought 8 (3):323-362.

Kaplan, Andras. 2014. "European management and European business schools: Insights from the history of business schools." European Management Journal 32 (4):529-534.

Kuhn, Thomas. 1962. The Structure of Scientific Revolutions. Chicago: The University of Chicago Press.

Le Ferrand, Hervé. 2014. Au sujet du mathématicien Hermann Laurent (1841-1908). HAL archives ouvertes.

Le Gall, Philippe. 2007. A history of econometrics in France. From Nature to Models. London: Routledge.

Le Gall, Philippe. 2008. "The confessions of the average: Statistics and natural order in nineteenthcentury French economic thought." History of political economy 40 (3):447-480.

Le Merrer, Pascal. 2011. "L'affirmation de l'économie comme discipline scientifique : une histoire française particulière." Tracés 11 (Hors-série):163-174.

Le Van-Lemesle, Lucette. 1991. "L'institutionnalisation de l'économie politique en France." In L'Economie Politique en France au XIXe Siècle, edited by Yves Breton and Michel Lutfalla, 335-388. Paris: Economica.

Leroy-Beaulieu, Paul. 1906. L'art de placer et gérer sa fortune. Paris: Librairie Ch. Delagrave.

Levasseur, Michel, and Yves Simon. 1980. Marchés de capitaux: options et nouveaux contrats à terme. Paris: Dalloz.

MacKenzie, Donald A. 2006. An engine, not a camera : how financial models shape markets, Inside technology. Cambridge, Mass.: MIT Press.

Marco, Luc. 2006. "L’agrégation de sciences de gestion." Revue d'histoire des sciences humaines 14:173-198.

Marco, Luc. 2018. Homo Gestor. Histoire de l'édition gestionnaire. Castres (Tarn): Édi-gestion.

Markowitz, Harry M. 1952. "Portfolio Selection." Journal of Finance 7 (1):77-91.

Mazliak, Laurent. 2015. "The Ghosts of the École Normale." Statistical Science 30 (3):391-412.

Medema, Steven G. 2011. "Textbooks as Data for the Study of the History of Economics: Lowly Beast or Fruitful Vineyard?", Working paper.

Mehrling, Perry. 2005. Fischer Black and the Revolutionary Idea of Finance. Hoboken: John Wiley \& Sons.

Ménard, Claude. 1980. "Three Forms of Resistance to Statistics: Say, Cournot, Walras." History of Political Economy 12:524-41.

Merton, Robert C. . 1973. "Theory of rational option pricing." Bell Journal of Economics and Management Science 4 (1):141-183. 
Montagne, Sabine. 2017. "From Benjamin Graham to Warren Buffett and John Bogle: the political meaning of the struggle between active and passive investors in the USA"." SASE 2017, Lyon (France).

Moore, Arnold B. 1964. "Some Characteristics of Changes in Common Stock Prices." In The Random Character of Stock Market Prices, edited by Paul H. Cootner, 139-161. Cambridge, Mass.: M.I.T. Press.

Mouillart, Michel. 1977. "La vérification du CAPM et la théorie des promenades aléatoires." Revue économique 28 (2):286-290.

Neymarck, Alfred. 1913. Que doit-on faire de son argent? Paris: Marchal et Godde.

Numa, Guy. 2004. "L'introduction de la modélisation financière dans les manuels français des années 1970." Master thesis, Université Paris-Dauphine.

Numa, Guy. 2017. "Charles Coquelin and Jules Dupuit on Banking and Credit." Journal of the History of Economic Thought 39 (2):239-256.

Pavis, Fabienne. 2003a. "L'institutionnalisation universitaire de l'enseignement de gestion en France (1965-1975)." Formation Emploi 83:51-63.

Pavis, Fabienne. 2003b. "Sociologie d'une discipline hétéronome. Le monde des formations en gestion entre universités et entreprises en France. Années 1960-1990." Doctorat, Sociologie, Université de Paris I-Panthéon- Sorbonne (419).

Platt, J. W., ed. 1963. Problèmes et perspectives de la formation à la gestion des entreprises en Europe (Rapport Platt). Paris: OCDE.

Pochet, Léon. 1873. "La géométrie des jeux de Bourse." Journal des Actuaires Français 2:153165.

Poitras, Geoffrey, ed. 2006. Pioneers offinancial economics: Contributions Prior to Irving Fisher. Vol. 1. Cheltenham, UK ; Northampton, MA: Edward Elgar.

Poitras, Geoffrey, and Franck Jovanovic, eds. 2007. Pioneers of financial economics: TwentiethCentury Contributions. Vol. 2. Cheltenham, UK ; Northampton, MA: Edward Elgar.

Pras, Bertrand. 2018. La FNEGE : 50 ans d'agilité pour l'enseignement de la gestion des entreprises. Paris: Vuibert - FNEGE.

Preda, Alex. 2009. Framing Finance: The Boundaries of Markets and Modern Capitalism. Chicago and London: University of Chicago Press.

Rosa, Jean-Jacques. 1972. "Equilibre et prix du risque sur le marché à terme de la Bourse de Paris." Journal de la Société de statistique de Paris 113:198-214.

Rosa, Jean-Jacques. 1976. "Rentabilité, risque et équilibre à la Bourse de Paris." Revue économique 27 (4):608-662.

Rosa, Jean-Jacques. 1977. "Réponse aux commentaires de M Mouillart." Revue économique 28 (2):290-295.

Rosenfeld, Félix. 1963. Analyse des valeurs mobilières. Paris: Dunod.

Rosenfeld, Félix. 1970. "La mesure des résultats de la gestion des portefeuilles de titres." Journal de la société statistique de Paris 111:208-222.

Rosenfeld, Félix. 1972. Analyse financière et gestion de portefeuille. Paris: Dunod.

Rosenfeld, Félix. 2002. Mémoires d'un Terrien du XXe siècle. Paris: Éd. des Écrivains.

Rutterford, Janette, and Dimitris Sotiropoulos. 2015. "Like the horses in a race': Financial diversification before modern portfolio theory." The 19th Annual Conference of the European Society for the History of Economic Thought (ESHET), Rome (Italy).

Savall, Henri. 1985. "Où va la recherche en sciences de gestion ?" Revue Française de Gestion 53-54 (septembre-décembre):242-269. 
Schmidt, Hartmut. 2009. "Retrospective book review on James Moser: 'Die Lehre von den Zeitgeschäften und deren Combinationen' (1875)." In Vinzenz Bronzin's option pricing models, edited by Wolfgang Hafner and Heinz Zimmermann, 467-470. Berlin: Springer.

Schöttler, Peter. 2015. "From Comte to Carnap. Marcel Boll and the introduction of the Vienna circle in France." Revue de synthèse 136 (1-2):207-236.

Servan-Schreiber, Jean-Jacques. 1967. le défi américain. Paris: Denoël.

Shafer, Glenn, and Vladimir Vovk. 2001. Probability and Finance: It's Only a Game! New York: Wiley.

Shafer, Glenn, and Vladimir Vovk. 2005. "The origins and legacy of Kolmogorov's Grundbegriffe." Working paper.

Sharpe, William F. 1964. "Capital Asset Prices: A Theory of Market Equilibrium under Conditions of Risk." Journal of Finance 19 (3):425-442.

Solnik, Bruno. 1973. "Note on the Validity of the Random Walk for European Stock Prices " The Journal of Finance 28 (5):1151-1159

Solnik, Bruno, and Gérard Stevenin. 1981. "Les primes et options à la Bourse de Paris." Banque 408 (Mai):561-568

Szpiro, George G. 2011. Pricing the Future : Finance, Physics, and the 300-Year Journey to the Black-Scholes Equation. New York, NY: Basic Books.

Taqqu, Murad S. 2001. "Bachelier and his Times: A Conversation with Bernard Bru." Finance and Stochastics 5 (1):3-32.

Teixeira, Pedro. 2018. "Conquering or mapping? Textbooks and the dissemination of human capital theory in applied economics." European Journal of the History of Economic Thought 25 (1):106-133.

Théodore, Gérard. 2008. "Félix Rosenfeld." The Survey Statistician 57 (January):27-29.

Vernimmen, Pierre. 1976. Finance d'entreprise : logique et politique. Paris: Dalloz.

Vicedo, Marga. 2012. "Introduction: The Secret Lives of Textbooks." Isis 103 (1):83-87.

Weber, Ernst Juerg. 2009. "A short history of derivative security markets." In Vinzenz Bronzin's option pricing models, edited by Wolfgang Hafner and Heinz Zimmermann, 431-466. Berlin: Springer.

Whitley, Richard Drummond. 1986. "The Rise of Modern Finance Theory: its characteristics as a scientific field and connection to the changing structure of capital markets." In Research in the History of Economic Thought and Methodology, edited by Warren J. Samuels, 147178. Stanford: JAI Press Inc.

Zajdenweber, Daniel. 1975. "Fluctuations des cours des actions cotées à la Bourse de Paris." 28/1975, Working paper.

Zajdenweber, Daniel. 1977. "La vérification du CAPM et la théorie des promenades aléatoires. A propos d'une controverse." Revue économique 28 (6):1005-1008.

Zisswiller, Richard. 1976. Micro-économie et analyse financière. Paris: Dalloz. 